\title{
Phosphorus distribution and sorption-release characteristics of the soil from newly submerged areas in the Danjiangkou reservoir, China
}

\author{
Zhixin Song $^{\mathrm{a}, \mathrm{b}}$, Baoqing Shan ${ }^{\mathrm{a}, \mathrm{b}, *}$, Wenzhong Tang ${ }^{\mathrm{a}, \mathrm{b}, *}$, Hong Zhang ${ }^{\mathrm{a}, \mathrm{b}}$, Chao Wang ${ }^{\mathrm{a}, \mathrm{b}}$, \\ Yu Zhao ${ }^{a, b}$ \\ a State Key Laboratory of Environmental Aquatic Chemistry, Research Center for Eco-Environmental Sciences, Chinese Academy of Sciences, Beijing 100085, \\ China \\ ${ }^{\mathrm{b}}$ University of Chinese Academy of Science, Beijing 100049, China
}

\section{A R T I C L E I N F O}

\section{Article history:}

Received 31 August 2016

Received in revised form

21 November 2016

Accepted 21 November 2016

Available online 27 November 2016

\section{Keywords:}

Newly submerged area

P

Distribution

Sorption-release

\begin{abstract}
A B S T R A C T
The phosphorus (P) distribution and sorption-release characteristics of the surface soil in new submerged areas from the Danjiangkou Reservoir were investigated, and assessed the potential risk of $\mathrm{P}$ released from the soils. The results indicated that the TP (total phosphorus) contents in the soils varied from $161.01 \mathrm{mg} / \mathrm{kg}$ to $1150.94 \mathrm{mg} / \mathrm{kg}$, and the mean content value of TP was the highest in arable land ( $732.91 \mathrm{mg} / \mathrm{kg}$ ), especially distributed in arable land above $160 \mathrm{~m}$ elevation; Calcium bound phosphorus ( $\mathrm{HCl}-\mathrm{P})$ was the major fraction of TP, the proportion was ranged from $60.77 \%$ to $83.38 \%$ for different land using types; the highest proportion of OP (organic phosphorus) was $32.07 \%$ in grass land soils. For all the samples, the rank order P-fractions was $\mathrm{HCl}-\mathrm{P}>\mathrm{OP}>\mathrm{NaOH}-\mathrm{P}$ (Phosphorus bound to $\mathrm{Al}$ and Fe oxides). Besides, the contents of TP correlated significantly with the HCl-P contents, $(r=0.936, \mathrm{P}<0.01), \mathrm{NaOH}-$ $P$ contents $(r=0.661, P<0.01)$, OP contents $(r=0.762, P<0.01)$, and IP contents $(r=0.970, P<0.01)$, but OP contents was no significantly correlated with HCl-P, NaOH-P contents. The sorption capacity of soil ranged from 578.79 to $1457.44 \mathrm{mg} / \mathrm{kg}$, and the amount of $\mathrm{P}$ released from the soils were ranged from 0.635 to $5.957 \mathrm{mg} / \mathrm{kg}$; however, due to the concentration of P in the overlying water, about $80 \%$ of the newly submerged area would act as sink of $\mathrm{P}$.
\end{abstract}

(c) 2016 Elsevier B.V. All rights reserved.

\section{Introduction}

Since 2002, China has been implementing the Middle Route of the South-to-North Water Diversion Project transferring water from the Danjiangkou Reservoir to the Huabei (north China region) for irrigation, domestic and industrial usage (Jarvie et al., 2005). After completion of the Danjiangkou Reservoir dam heightening project, the storage level increased from 157 to $170 \mathrm{~m}$, and large soil areas are submerged by water, which has potential ecological risk due to previous human activities in the newly submerged areas. The $P$ accumulated in newly submerged area could be releasing into the water, and affecting the water quality (Ulen et al., 2007), causing eutrophication of reservoir (McDowell et al., 2002). However, there is very little known about the distribution characteristics and $P$ release risk in newly submerged area.

\footnotetext{
* Corresponding authors at: State Key Laboratory of Environmental Aquatic Chemistry, Research Center for Eco-Environmental Sciences, Chinese Academy of Sciences, Beijing 100085, China.

E-mail addresses: bqshan@rcees.ac.cn (B. Shan),wztang@rcees.ac.cn (W. Tang).
}

$\mathrm{P}$ is a major contributor to the eutrophication of freshwater ecosystems, and in most freshwater systems it limits primary production (Edwards and Withers, 2007), its excess supply can lead to eutrophication (Schindler et al., 2008). When the external loading of $\mathrm{P}$ increased, the soils act as a sink can absorb it (Sattari et al., 2012). However, after the external loading is reduced, the soils as a source would release the adsorbed P back into water (Williams et al., 1970). The characteristics of soils, environmental factors, and concentration of P in the overlying water (Kronvang et al., 2005), will affect the transfer direction of phosphate on the interface of the soil-water (Carpenter, 2005). P in soils of newly submerged area of the Danjiangkou Reservoir would have physical, chemical and biological exchanges through overlying water (Williams et al., 1971). Therefore, under certain conditions, the soil may acts as a source or sink for P that can affect the trophic status of the Danjiangkou Reservoir (Eveborn et al., 2014). However, not all of the P fractions can be released from soils into the overlying water (Dong et al., 2011), the $\mathrm{P}$ behavior in soils for promoting reservoir eutrophication can be more efficiently evaluated based on the P fractions (Huo et al., 2011). The aims of this study were to investigate the characteristics of the phosphorus fractions (inorganic P (IP)), calcium-bound 
$\mathrm{P}$ extracted using hydrochloric acid ( $\mathrm{HCl}-\mathrm{P}), \mathrm{Al}$ and $\mathrm{Fe}$ oxide- and oxyhydroxide-bound $\mathrm{P}$ extracted using sodium hydroxide $(\mathrm{NaOH}-$ $\mathrm{P})$, organic P (OP), OP, and TP according to the SMT (standards, measurements and testing) protocol (Ruban et al., 1999; Ahlgren et al., 2011), and according to different land use types and elevation, describe isotherms of P sorption, to calculate the characteristics of the P sorption or release from the soils of the newly submerged area, and assessment risk of potential phosphorus release situation.

\section{Experimental}

\subsection{Study area}

The Danjiangkou Reservoir $\left(32^{\circ} 360^{\prime}-33^{\circ} 480^{\prime} \mathrm{N}\right.$, $110^{\circ} 590^{\prime}-111^{\circ} 490^{\prime} \mathrm{E}$ ) is located in the juncture of Hubei and Henan province, China (Fig. 1), built in 1970s, area of water surface is $745 \mathrm{~km}^{2}$. It has a subtropical monsoon humid climate, with an average annual temperature is $15.8^{\circ} \mathrm{C}$, and an average annual precipitation is $804.3 \mathrm{~mm}$, rainfall in the area is abundant but uneven, and mainly precipitation in July and September. The first phase of Danjiangkou Reservoir dam was completed in 1973 and the storage level is $157 \mathrm{~m}$ (water level above sea), after the 2nd phase completed in 2014, the storage level up to $170 \mathrm{~m}$, the area of newly submerged land up to $307.7 \mathrm{~km}^{2}$, covered 26 counties (cities) of Henan and Hubei province. The water periodic scheduling would take place from May 1 to June 21 every year. The water level would be gradually reduced from $170 \mathrm{~m}$ to $160 \mathrm{~m}$ in summer. On August 21, the reservoir allowed gradually began filling water up to $163.5 \mathrm{~m}$. After October 1, the reservoir was filled to the normal storage level of $170 \mathrm{~m}$. During this period (one year), the water level fluctuates between $160 \mathrm{~m}$ and $170 \mathrm{~m}$, indicating a variation in water level of up to $10 \mathrm{~m}$ in the submerged land zone.

The study area was located at the main newly submerged area, in Xichuan, which are tributaries to Henan province. A map of the study area is shown in Fig. 1. Basic information of the sampling sites distribution and the number of sampling sites between in different elevation zones as shown in Table S1.

\subsection{Sample collection and analysis}

Based on the high-resolution remote-sensing images of the Danjiangkou Reservoir area, we divided the newly submerged area into several investigation units, as shown in Table S1. We designed the scheme according to the samples site uniformity, representativeness, feasibility principle, and percentage of different land using types of total the newly submerged area. Using GPS (Global Positioning System) positioning and sampling soils in each survey unit (Fig. 1), and 92 samples were collected. Sampling points were distributed evenly in new submerged area of Xichuan County; covered the different land using types and elevation (Table S1). In July 2014, the sample were collected surface to $10 \mathrm{~cm}$ depth soil samples (Peng et al., 2007), the samples sealed polyethylene bags, keep in $4{ }^{\circ} \mathrm{C}$ condition. Upon arrival in laboratory, the samples were freeze dried by using FD-1A-50 freeze drier, and then mixed thoroughly.

Organic matters (SOM) in sediment were determined by loss of ignition at $550^{\circ} \mathrm{C}$ for $4 \mathrm{~h}$. The grain-size distribution was determined by laser particle size analyzer (Mastersizer 2000, Malvern, USA) and classified into clay $(<0.002 \mathrm{~mm})$, silt $(0.002-0.05 \mathrm{~mm})$, and sand $(0.05-2 \mathrm{~mm}$ ) (Gee and Bauder, 1986). The contents of main elements in soil were measured by atomic absorption spectrometry.

\subsection{Phosphorus fractions}

The soil samples were sieved with a standard 100-mesh sieve, and sequential P fraction was carried out by using the SMT pro- cedure (Zhu et al., 2013), as shown in Fig. S1. The SMT protocol, proposed by the Community Bureau of Reference, was applied to extract five P fractions: IP, HCl-P, NaOH-P, OP and TP (Zhang et al., 2012). P was separated into five fractions by this method. $P$ bound to $\mathrm{Al}, \mathrm{Fe}$, and $\mathrm{Mn}$ oxides and oxyhydroxides were extracted by $\mathrm{NaOH}$. $\mathrm{P}$ bound to calcium was extracted using $\mathrm{HCl}$ and the residual $\mathrm{P}$ was treated at $450^{\circ} \mathrm{C}$ to produce the OP fraction. The TP in the soils was determined by processing the sample at $450^{\circ} \mathrm{C}$, followed by $\mathrm{HCl}$ extraction. The $\mathrm{P}$ concentrations in the supernatant of the extractions were analyzed by using the molybdenum blue method (Jin et al., 2013).

\subsection{Phosphate sorption kinetic experiments}

Dried soil samples $(0.5 \mathrm{~g})$ were added in a series of $100 \mathrm{ml}$ acidwashed screw-cap centrifuge tubes with $50 \mathrm{ml} \mathrm{P}$ solution $\left(\mathrm{KH}_{2} \mathrm{PO}_{4}\right.$, containing $10 \mathrm{mg} / \mathrm{LP}$ ). Besides, two drops of chloroform were added to inhibit the bacterial activity. The centrifuge tubes were capped and incubated at $25 \pm 1{ }^{\circ} \mathrm{C}$ in an orbital shaker at $200 \mathrm{rpm}$ for different time intervals, varying within $64 \mathrm{~h}(0,0.25,0.5,1,2,3,5,7,9,18$, $27,36,48$, and $64 \mathrm{~h}$ ). The samples were immediately centrifuged at $4390 \times \mathrm{g}$ for $15 \mathrm{~min}$, and filtered through $0.45 \mu \mathrm{m} \mathrm{GF} / \mathrm{C}$ filter membrane, the results described in following sections are mean of three analyzing parallel samples (Pan et al., 2013).

\subsection{Phosphate sorption isotherm experiments}

We determined the dissolved phosphorus concentration at which there is no net adsorption or release of dissolved $\mathrm{P}$ from soils (equilibrium $\mathrm{P}$ concentration value, $\mathrm{EPC}_{0}$ ). To determine $\mathrm{EPC}_{0}$ for each soil samples, $0.5 \mathrm{~g}$ sample were put into the $100 \mathrm{ml} \mathrm{screw}$ cap centrifuge tubes and $50 \mathrm{ml} \mathrm{P}$ standard solutions (anhydrous $\mathrm{KH}_{2} \mathrm{PO}_{4}$ ) of various concentrations ranged from $0 \mathrm{mg} / \mathrm{L}$ to $20 \mathrm{mg} / \mathrm{L}$ $(0,0.05,0.1,0.2,0.5,1.0,2.0,5.0$ and $10.0 \mathrm{mg} / \mathrm{L} \mathrm{P})$. The conditions of the other experiments were the same as that of the adsorption kinetics experiments. After equilibration, the solutions were centrifuged at $4390 \times g$ for $15 \mathrm{~min}$ and supernatants were removed for $P$ analysis (Jin et al., 2013).

In order to evaluate whether the settled matter as sediment acted as a sink or source in the water system, modified Langmuir adsorption model was used to obtain the equilibrium $P$ concentration value $\left(\mathrm{EPC}_{0}\right)$. The phosphate sorption capacity was fitted by Lopez et al. (Lopez et al., 1996)

$\mathrm{Q}=\frac{\mathrm{Q}_{\max } \times C}{K_{d}+C}$

where $C$ is the $P$ sorption equilibrium concentration $(\mathrm{mg} / \mathrm{L}), \mathrm{Q}$ is the P sorption capacity ( $\mathrm{mg} / \mathrm{kg}$ dry weight) and is the absorbed $\mathrm{P}$ when the equilibrium is reached, $\mathrm{Q}_{\max }$ is the maximum $\mathrm{P}$ sorption capacity ( $\mathrm{mg} / \mathrm{kg}$ dry weight), $\mathrm{K}_{\mathrm{d}}$ is the half-saturation concentration $(\mathrm{mg} / \mathrm{L})$, i.e., the phosphate concentration that must be added to obtain an sorption equal to the half $\mathrm{Q}_{\max }$, and the slope of sorption isotherm is a measure of the P sorption efficiency of sediments (Zhang et al., 2012).

In order to judge whether the soil acts as a source or sink of $P$ for the surface water (Pan et al., 2002), defined a criterion of $\lambda=\mathrm{C} / \mathrm{EPC}_{0}$, and Jarvie defined $\mathrm{EPC}_{\mathrm{sat}}=\left(\left(\mathrm{EPC}_{0}-\mathrm{DIP}\right) / \mathrm{EPC}_{0}\right) \times 100 \%$, DIP (dissolved inorganic phosphate) (Jarvie et al., 2014). However, $\mathrm{EPC}_{0}$ is in the denominator in both equations, both of the methods could easily enlarge the measurement error especially when $\mathrm{EPC}_{0}$ is low. Here, we developed a new simple criterion $\delta$. According to Eq. (1) adsorption isotherm, $\mathrm{EPC}_{0}$ is the zero equilibrium concentration $(\mathrm{mg} / \mathrm{L}), \mathrm{C}_{\mathrm{eq}}$ is the concentration of DIP in water samples. We define:

$\delta=C_{e q}-E P C_{0}$ 


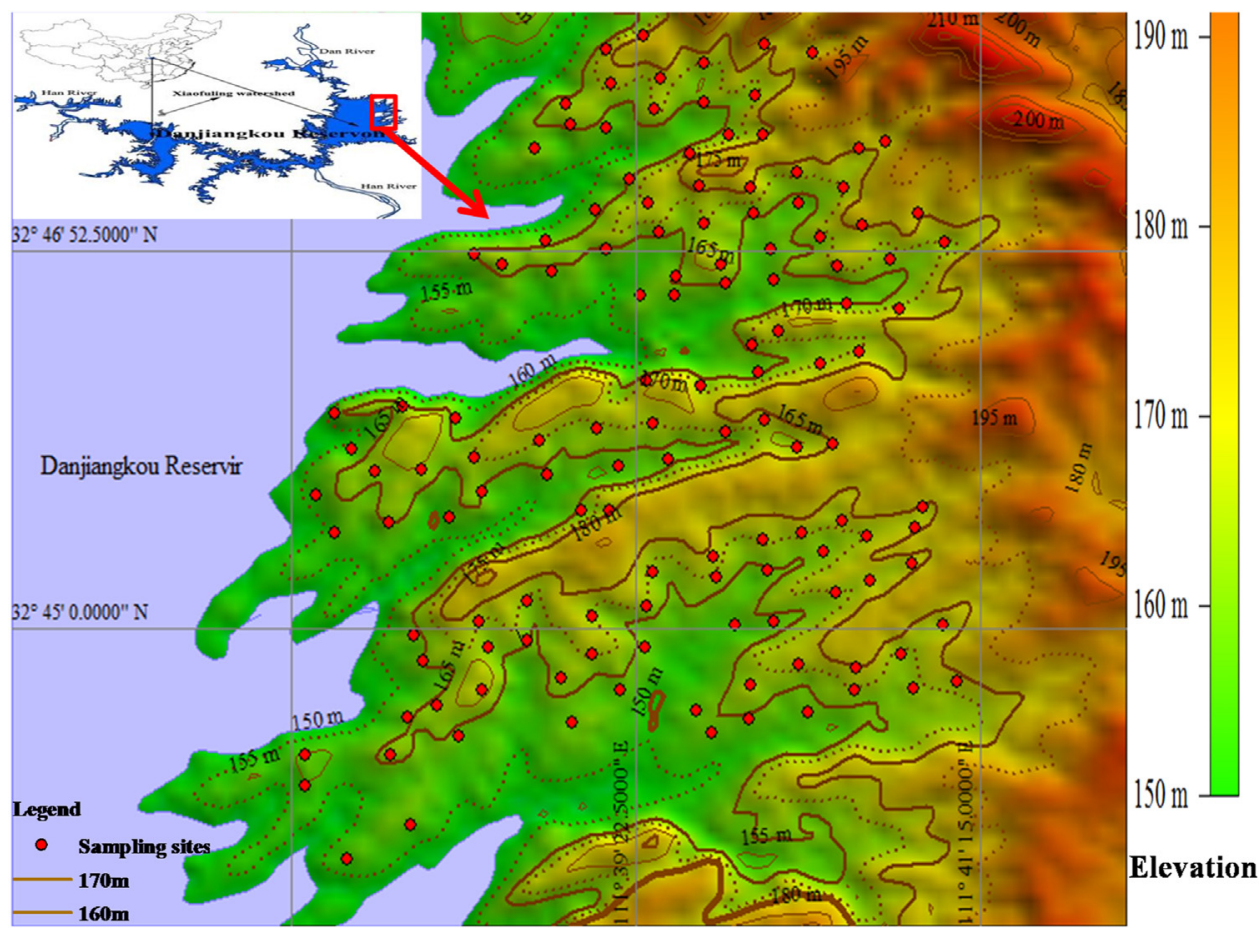

Fig. 1. Map of the study area in the Danjiangkou Reservoir, with the sampling sites indicated on the new submerged area in Xichuan, Henan province.

Table 1

Physical and chemical characteristics of soils in the newly submerged area of the Danjiangkou Reservoir (SD: Standard deviation).

\begin{tabular}{lllll}
\hline Item & Range & Mean & Median & SD \\
\hline SOM $(\mathrm{mg} / \mathrm{kg})$ & $7654.32-20827.67$ & 12568.11 & 11432.21 & 6544.28 \\
$\mathrm{TP}(\mathrm{mg} / \mathrm{kg})$ & $161.01-1150.94$ & 498.09 & 534.69 & 206.42 \\
$\mathrm{Al}(\mathrm{mg} / \mathrm{kg})$ & $45763.78-79762.23$ & 62015.56 & 63211.47 & 9712.43 \\
$\mathrm{Fe}(\mathrm{mg} / \mathrm{kg})$ & $28926.82-44783.36$ & 36344.44 & 34872.28 & 4463.81 \\
$\mathrm{Mn}(\mathrm{mg} / \mathrm{kg})$ & $457.89-723.46$ & 572.88 & 560.43 & 134.93 \\
$\mathrm{Ca}(\mathrm{mg} / \mathrm{kg})$ & $5242.31-45327.94$ & 16617.78 & 10538.92 & 11946.22 \\
$\mathrm{Clay}(\%)$ & $3.52-12.98$ & 9.51 & 11.23 & 7.36 \\
Silt $(\%)$ & $51.96-71.93$ & 63.96 & 65.32 & 26.31 \\
Sand $(\%)$ & $18.23-35.82$ & 26.54 & 28.14 & 27.17 \\
\hline
\end{tabular}

when $\delta<0$ (desorption), sediment is a source of P; When $\delta>0$ (adsorption), sediment is a sink for P.

\subsection{Statistical analysis}

Sample points distribution was generated using ArcGIS 9.3; the data was analyzed using SPSS 16.0. Origin Pro 8.5 software was used to plot the data. Two-sample $t$-tests $(\mathrm{p}<0.05)$ were used to assess the differences between groups of data. All of the results used were averages of the results found from analyzing three parallel samples (samples are from each sampling site).

\section{Results and discussion}

\subsection{Soil characteristics}

The general physical and chemical component contents of the soils in the newly submerged area of the Danjiangkou Reservoir are presented in Table 1. The SOM accounting for $7654.32-20827.67 \mathrm{mg} / \mathrm{kg}$ of the total samples, and the standard deviation was 6544.28 , the SOM contents could affect the P fractions in the soils, and since the SOM contents in grassland soils were very high. Silt was the major particle fraction (51.96\%-71.93\%) and the lowest values were found in sampling sites from bare land. Clay was the minor fraction, ranged from $2.69 \%$ to $12.98 \%$. All the components were mainly affect $P$ mobility from the soils to the water column (Mellander et al., 2013).

\subsection{P distribution and fractions}

We were firstly to analyze $P$ and fractions in samples from different land using types, as shown in Fig. 2(a). The mean content values of TP in arable land soil was $732.91 \mathrm{mg} / \mathrm{kg}$, higher than in other land use types, which may be due to the various different compositions of arable soils caused by human activities such as agricultural production activities or domestic sewage discharged (Pionke et al., 2000). The content values of TP were the smallest in bare land (mean value $288.57 \mathrm{mg} / \mathrm{kg}$ ). It was indicated that the arable land was affected by anthropogenic sources and enhanced $\mathrm{P}$ contents.

The mean content values of $\mathrm{HCl}-\mathrm{P}$ were higher in arable land and other land (construction land and wasteland), were 546.92 and $365.93 \mathrm{mg} / \mathrm{kg}$ respectively, while grass land, woodland, and bare land were relatively lower. The mean content values of NaON-P followed a decreasing sequence for arable land $>$ grassland $>$ woodland $>$ other land $>$ bare land.

The mean content values of OP in grassland were strongly affected by rich microbial and SOM sources, and higher than other land use types (Storkey et al., 2015), due to grass led to enhanced rates of P cycling, increasing $\mathrm{P}$ solubility (Borggaard et al., 2005). Grass land Soils had increased dissolved organic P, phosphatase enzyme activity, microbial diversity, and biomass $P$, compared with other land using types (Lazzarotto et al., 2005).

For all the soil samples, P-fractions were in rank order of $\mathrm{HCl}$ $\mathrm{P}>\mathrm{OP}>\mathrm{NaOH}-\mathrm{P}$, except for O-L, as shown in Fig. 2(b). For the HCl-P, the highest proportion in other land was $83.38 \%$ (average), $60.77 \%$ was the lowest in Wasteland. For $\mathrm{NaOH}-\mathrm{P}$, the highest proportion was $10.8 \%$ in bare land, and $2.19 \%$ was for other land. In many studies, the IP is the sum of HCl-P and $\mathrm{NaOH}-\mathrm{P}(\mathrm{IP}=\mathrm{HCl}-\mathrm{P}+\mathrm{NaOH}-\mathrm{P})$ (Jin et al., 2013). IP was the major phosphorus fraction in soils, which was an important source of bioavailable phosphorus in eutrophic 
(a)
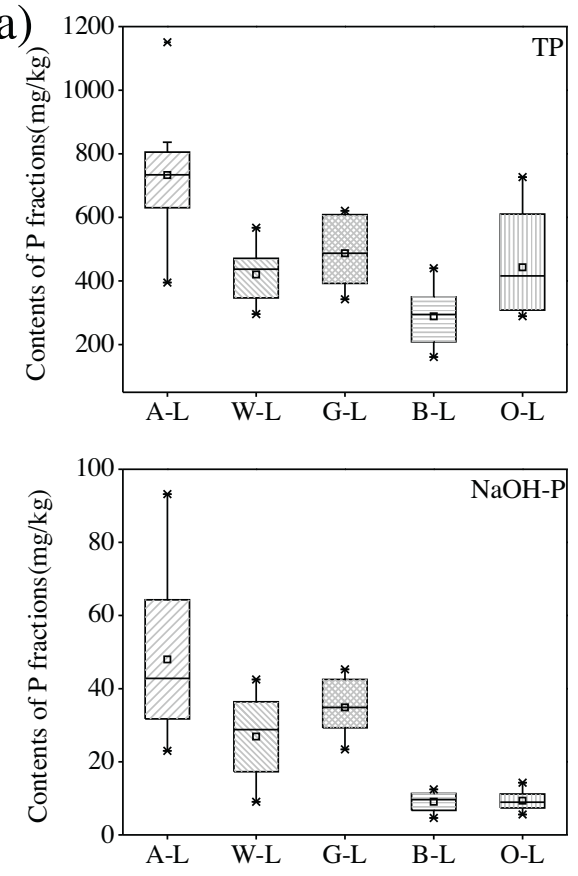
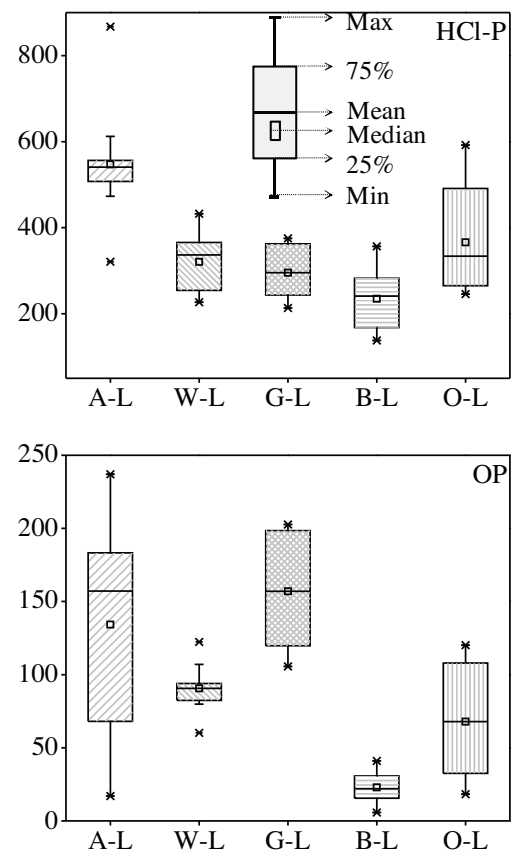

(b)

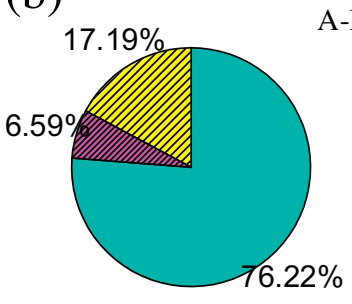

$7.55 \%$

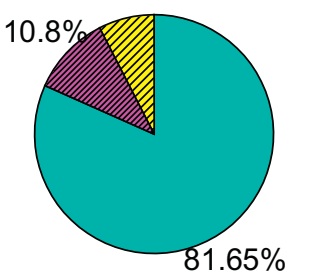

A-L

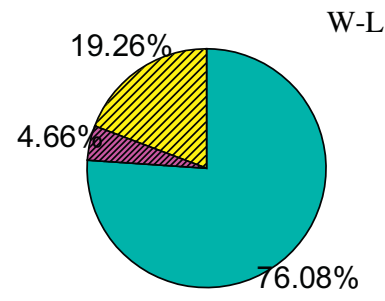

B-L

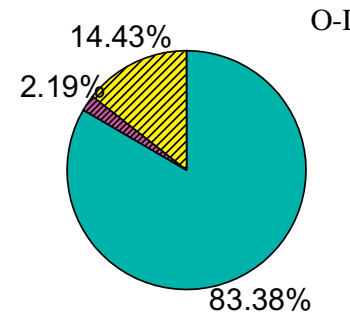

G-L

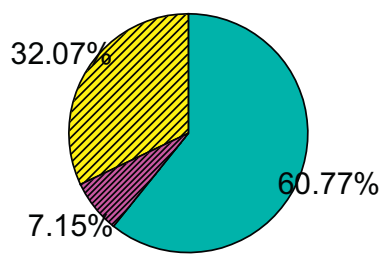

O-L
HCl-P

$\mathrm{NaOH}-\mathrm{P}$

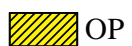

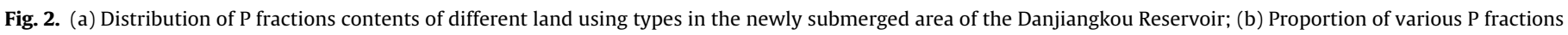
in soils by SMT. (A-L: arable land, W-L: woodland, G-L: grassland, B-L: bare land, O-L: other land).

sediments (Ribeiro et al., 2008). For O-P, 32.07\% for grassland was the highest proportion and the lowest was $7.55 \%$ in bare land. Based on the results of sequential extraction of $\mathrm{P}$, lability and bioavailability was in decreasing rank order as follows: $\mathrm{NaOH}-\mathrm{P}>\mathrm{OP}>\mathrm{HCl}-\mathrm{P}$. Therefore, the biogeochemical cycle of $\mathrm{NaOH}-\mathrm{P}$ and OP might play an important role induced the eutrophic status of Danjiangkou Reservoir (Lin et al., 2009). According to the results, the arable land was main zone contributed significantly to $P$ release during a water storage period, and $51.7 \%$ of the total newly submerged area in the Danjiangkou Reservoir was designated as arable land, thus it was important to explore the distribution characteristics of $\mathrm{P}$ in the arable land. Besides, it unwise to establish grass buffer strips in the newly submerged area, because grass buffer strips may be increasing the susceptibility P move to adjoining water (Stutter et al., 2009).

\subsection{Identifying the potential $P$ release zone}

One of purposes in this study was to identify which was the potential P release zone during a water storage period that should be given more attention, especially about the arable land. The results indicated that arable land was the main potential $P$ release area, and the standard deviation values fluctuated considerably. Therefore, we were to consider the sampling sites at different elevation, and attempt to produce an accurate estimation of P distribution in arable land. The $P$ fractions were analyzed in different elevation, as shown in Fig. 3. The TP and HCl-P contents increased with elevation, $\mathrm{NaOH}-\mathrm{P}$ and $\mathrm{OP}$ contents were higher at arable land above $160 \mathrm{~m}$ elevation. For example, the mean content values of TP in arable land at "<160 m", “160-165 m", "165-170 m" and “>170 m" elevation were 549.0, 726.37, 748.01, and $740.79 \mathrm{mg} / \mathrm{kg}$, respectively, the mean content values of $\mathrm{HCl}-\mathrm{P}$ were 473.21, 513.15, 


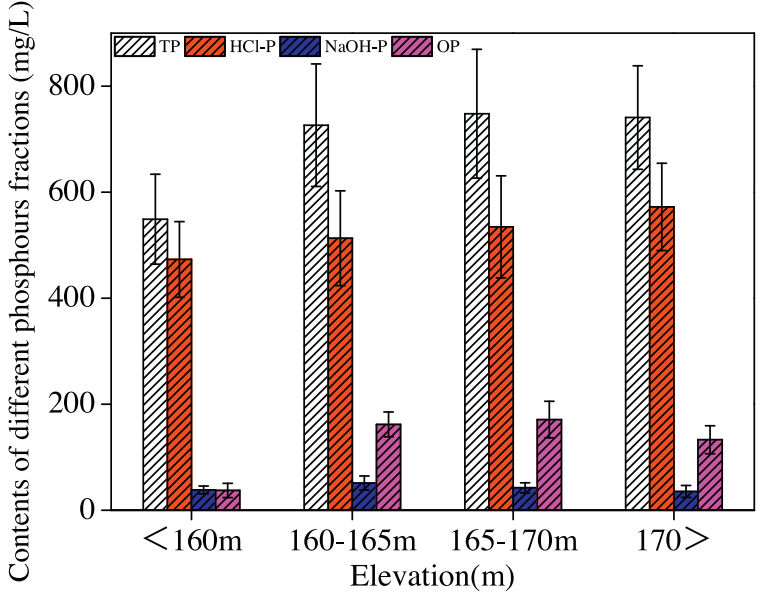

Fig. 3. Contents of different $P$ fractions in arable land soils at different elevation.

Table 2

The correlation coefficients between various phosphorus fractions in samples $(n=92)$.

\begin{tabular}{llllll}
\hline & TP & HCl-P & NaOH-P & OP & IP \\
\hline TP & 1 & & & & \\
HCl-P & $0.936\left(^{* *}\right)$ & 1 & & & \\
NaOH-P & $0.661\left(^{* *}\right)$ & -0.387 & 1 & & \\
OP & $0.762\left(^{* *}\right)$ & 0.272 & 0.443 & 1 & \\
IP & $0.970\left({ }^{* *}\right)$ & $0.995\left(^{* *}\right)$ & $0.664\left(^{*}\right)$ & $0.581\left(^{*}\right)$ & 1 \\
\hline
\end{tabular}

${ }^{*} P<0.05$ : Correlation significant at the 0.05 level (2-tailed).

** $P<0.01$ : Correlation significant at the 0.01 level (2-tailed).

Table 3

Pearson correlation coefficients between the $\mathrm{P}$ fractions and soils compositions contents analyzed in samples. $(n=92)$.

\begin{tabular}{llllll}
\hline & TP & HCl-P & NaOH-P & OP & IP \\
\hline SOM & 0.353 & 0.284 & 0.338 & 0.743 & 0.339 \\
$\mathrm{Al}$ & 0.375 & -0.144 & 0.225 & 0.134 & 0.489 \\
Fe & 0.221 & 0.495 & -0.116 & -0.472 & 0.568 \\
Mn & -0.235 & 0.468 & -0.334 & -0.538 & 0.367 \\
Ca & -0.403 & 0.287 & -0.354 & -0.567 & 0.312 \\
\hline
\end{tabular}

534.62 , and $572.32 \mathrm{mg} / \mathrm{kg}$, and the OP contents in arable land at " $<160 \mathrm{~m}$ " elevation lower than in arable land at "> $160 \mathrm{~m}$ " elevation. The mean content value of $\mathrm{NaOH}-\mathrm{P}$ was similar in different elevation and the highest at "160-165 m" elevation. Overall, the results revealed that the arable land at above $160 \mathrm{~m}$ elevation was major risk area, and the content values of TP were low at below $160 \mathrm{~m}$ elevation of arable land. It was due to the periodic flooding reduces $P$ of the surface soil (Aye et al., 2006), or because the local farmers worried about the crops would be flooded sometime and reduced input of investments such as fertilizer. The areas of 160-170 m elevation in the newly submerged area were swamped between October and May (the next year), the mean temperature was about $10.7^{\circ} \mathrm{C}$ during the period, and microbial activity was low, which may reduce the potential risk of eutrophication to the water (Sondergaard et al., 2013).

The relationships between $P$ fractions and soils compositions contents in the newly submerged area of Danjiangkou Reservoir were analyzed using the Pearson correlation coefficients (Tables 2 and 3). The TP contents correlated significantly with the HCl-P contents, $(r=0.936, P<0.01)$, NaOH-P contents $(r=0.661$, $P<0.01)$, OP contents $(r=0.762, P<0.01)$, IP contents $(r=0.970$, $P<0.01$ ), $\mathrm{HCl}-\mathrm{P}$ contributed substantially to the supply of IP in the soils, thus IP contents correlated significantly with $\mathrm{HCl}-\mathrm{P}, \mathrm{NaOH}-$ $\mathrm{P}$ and OP contents. OP contents were no significantly correlated with $\mathrm{HCl}-\mathrm{P}, \mathrm{NaOH}-\mathrm{P}$ contents. There were no significant relation- ships between $\mathrm{P}$ fractions and $\mathrm{Al}, \mathrm{Fe}, \mathrm{Mn}$ and $\mathrm{Ca}$ contents. Though $\mathrm{Fe}$ and Al may contribute significantly to phosphorus bioavailability in soils by enhancing the cation-exchange capacity and reducing the phosphorus fixation (Zhang and Huang, 2007; Dunne et al., 2013). The TP, IP, HCl-P, and NaOH-P contents were no significantly correlated with SOM, except OP contents. Similar results were also reported in the river delta, lake and reservoir sediments (Zhang et al., 2008).

\subsection{The sorption kinetics and isotherm of phosphate on soils}

In order to judge whether the soils act as a source or sink of $\mathrm{P}$ for the water body during a water storage period, we set a groups of adsorption experiments. The soil samples came from arable land from 160 to $170 \mathrm{~m}$ elevation areas of the newly submerged area. The TP contents of samples were as follows: A: $1050.94 \mathrm{mg} / \mathrm{kg}, \mathrm{B}$ : $816.95 \mathrm{mg} / \mathrm{kg}, \mathrm{C}: 693.4 \mathrm{mg} / \mathrm{kg}, \mathrm{D}: 534.69 \mathrm{mg} / \mathrm{kg}, \mathrm{E}: 367.2 \mathrm{mg} / \mathrm{kg}, \mathrm{F}$ : $261.3 \mathrm{mg} / \mathrm{kg}$, which represent a uniform distribution of different TP contents. The P sorption kinetic results are shown in Fig. 4(a). The $\mathrm{P}$ sorption rate was increased rapidly with time increasing within $2 \mathrm{~h}$, slowed down gradually before $10 \mathrm{~h}$, After $20 \mathrm{~h}$, the sorption was reached to equilibrium. The sorption kinetics was similar among the other studied soils samples. The sorption rate was used to describe the P sorption capacity by the soils, which was the slope of the curve, from Fig. 4 we could saw the sorption rates of $0-0.5 \mathrm{~h}$ were the highest within $64 \mathrm{~h}$, ranged from 49.91 to $86.3 \mathrm{mg} / \mathrm{kg} \mathrm{h}$ (shown in Table S2). The results indicated that a quick sorption process was mainly within $0.5 \mathrm{~h}$. P sorption on soil was mainly depended on its physical and chemical properties. The similar results were also reported in shallow lakes in the middle and lower reaches of Yangtze River region in China (Zhang et al., 2012).

In the second set of adsorption experiments, according to sorption kinetics and ascertain equilibration time was $20 \mathrm{~h}$, thus centrifuge tubes were capped for $20 \mathrm{~h}$. The sorption isotherms of $\mathrm{P}$ on the soils were shown in Fig. 4(b). The adsorption isotherms crossed over the aqueous concentration axis. It was due to natural particles often containing NAP (the amount of total native adsorbed $\mathrm{P}$ ) before they are used in experiment. Under temperature conditions of $25^{\circ} \mathrm{C}$, the experimental data fits well into Eq. (1). In addition, the $\mathrm{Q}_{\max }$ sorption capacity was varied from 578.79 to $1457.44 \mathrm{mg} / \mathrm{kg}, \mathrm{K}_{\mathrm{d}}$ ranged from 2.53 to $4.08 \mathrm{mg} / \mathrm{L}$. When P adsorbed falls to zero, the equilibrium concentration of $P$ in trial solution $(C)$ is equal to $\mathrm{EPC}_{0}: \mathrm{C}=\mathrm{EPC}_{0}$, and the system is already in equilibrium without net adsorption or desorption.

To confirm that $P$ could be released from the soil back into the water when the water DIP concentration was lower than $\mathrm{EPC}_{0}$, it involved placing the soil samples into ultra-pure water. It was found that soil acted as a new pollutant source to release $P$ into the overlying water. The amount of $P$ released by the soils was ranged from 0.635 to $5.957 \mathrm{mg} / \mathrm{kg}$. The proportion of the released $P$ ranged from $0.143 \%$ to $0.569 \%$. The amount of $P$ released from the sediments had a positive relationship with the TP contents level (Siciliano et al., 2016). However, no correlation was found between the amount of P released from the soils and the HCl-P contents. It was implied that only some of the $P$ fractions could be released from soils into the overlying water. The $\mathrm{NaOH}-\mathrm{P}$ could easily be released from soils and was identified as the major fraction of soils influencing the P distribution in the overlying water (Pan et al., 2013). In many eutrophic reservoirs, oxygen penetration into the sediments is limited within a confined layer and the release of $P$ was attributed to reduction of iron hydroxides and iron phosphate under anoxic conditions (Ahlgren et al., 2005). The major controlling factor of $\mathrm{P}$ released into reservoir may be mediated processes by Fe reduction due to oxygen depletion (Wilfert et al., 2015). Meanwhile, the reservoir with high value of $\mathrm{pH}, \mathrm{P}$ would be liberated from the FeOOH-P 
(a)

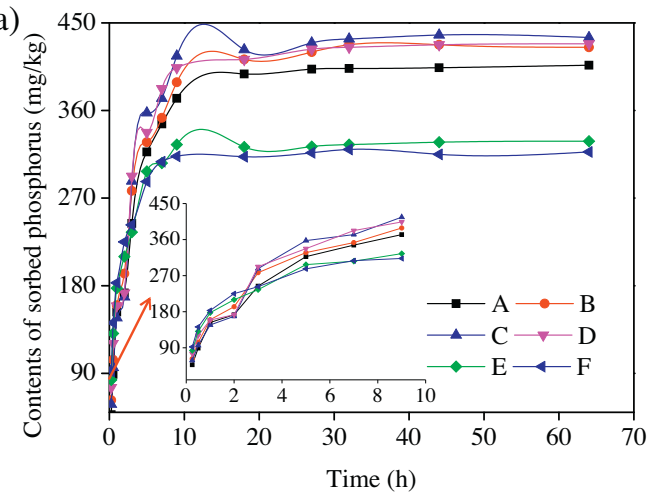

(b)

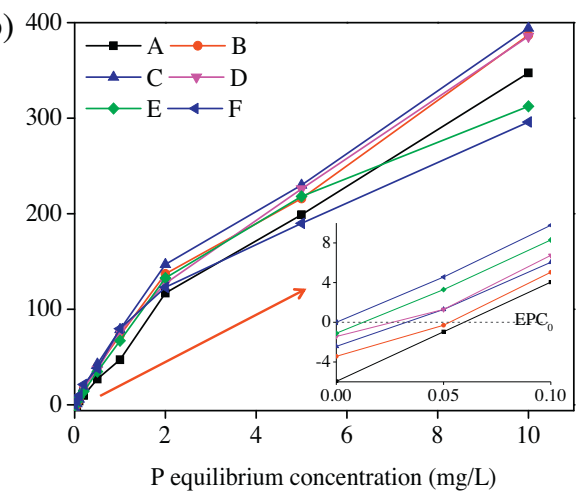

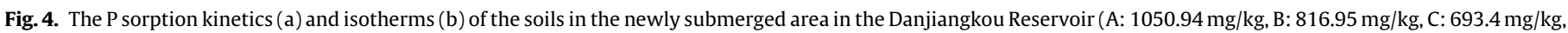
D: $534.69 \mathrm{mg} / \mathrm{kg}, \mathrm{E}: 367.2 \mathrm{mg} / \mathrm{kg}, \mathrm{F}: 261.3 \mathrm{mg} / \mathrm{kg}$ ).

Table 4

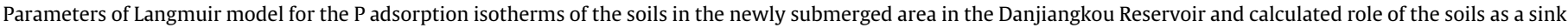
or source of $P$.

\begin{tabular}{|c|c|c|c|c|c|c|}
\hline sampling & $\mathrm{Q}_{\max }(\mathrm{mg} / \mathrm{kg})$ & $\mathrm{K}_{\mathrm{d}}(\mathrm{mg} / \mathrm{L})$ & $\mathrm{EPC}_{0}(\mathrm{mg} / \mathrm{L})$ & $\mathrm{R}^{2}$ & $\delta$ & sink/source \\
\hline A & 1457.44 & 4.08 & 0.065 & 0.9873 & -0.036 & Source \\
\hline B & 1244.45 & 3,26 & 0.0434 & 0.9806 & -0.0144 & Source \\
\hline C & 1130.9 & 3.69 & 0.0322 & 0.9884 & -0.0032 & Source \\
\hline D & 963.19 & 2.87 & 0.0262 & 0.9901 & 0.0028 & Sink \\
\hline $\mathrm{E}$ & 695.7 & 3.42 & 0.0064 & 0.9826 & 0.0226 & Sink \\
\hline $\mathrm{F}$ & 578.8 & 2.53 & 0.0045 & 0.9973 & 0.0245 & sink \\
\hline
\end{tabular}

pool due to competition with $\mathrm{OH}^{-}$ions (Pardo et al., 2004). The competition capacity can be excluded as a possible mechanism that contributes to $\mathrm{NaOH}-\mathrm{P}$ from the overlying water. Therefore, $\mathrm{NaOH}-$ $P$ fraction may contribute to P-released from soils by enhancing the reduction of both the $\mathrm{P}$ ion-competition and fixation capacity. Although the content of NaOH-P was low, the P behavior in soils could efficiently be evaluated based on the $\mathrm{NaOH}-\mathrm{P}$ fraction.

The sorption capacity and efficiency were compared with some soil physical and chemical parameters. The correlation coefficients among soil compositions indicate that there was no significant correlation between soil compositions and the maximum phosphate sorption capacity, and phosphate sorption efficiency. However, some studies have shown that the maximum phosphate sorption capacity was significantly correlated with Fe, TOC, TN, TP, Ca, and IP contents (Baliarsingh et al., 2013), the ratio of $\mathrm{NaOH}-\mathrm{P}$ and the $\mathrm{P}$ sorption efficiency were positively related to Fe content in the sediment of shallow lakes in the middle and lower reaches of Yangtze River region.

The calculated data of $\mathrm{Q}_{\max }, \mathrm{K}_{\mathrm{d}}, \mathrm{EPC}_{0}, \mathrm{R}^{2}$, and $\delta$ were listed in Table 4. The concentrations of $\mathrm{P}$ in the overlying water in the Danjiangkou Reservoir was ranged from 0.017 to $0.0468 \mathrm{mg} / \mathrm{L}$, and mean values was $0.032 \mathrm{mg} / \mathrm{L}\left(\mathrm{C}_{\mathrm{eq}}\right)$. If $\delta<0$, the net effect of sorption was the release of NAP from the natural soils (soils serves as source of $\mathrm{P}$ ). On the other hand, if $\delta>0$, the net effect of sorption was $P$ uptake by soils (soils serves as sink of $\mathrm{P}$ ). In this study, the $\mathrm{EPC}_{0}$ of $A, B$ and $C$ values were higher than the mean concentration values of DIP in the Danjiangkou Reservoir water, $\delta<0$, which indicated that only some sites of the soils act as source of $P$ release into the overlying water. The higher contents of TP in soils, the greater release will be. The newly submerged area in the Danjiangkou Reservoir become a weak sink of $P$ as the $\delta$ values become negative, the soils of D, E and F represent the sink of sites, as the TP level in the sample is relatively low. Therefore, about $20.33 \%$ of all samples can release $\mathrm{P}$ to water when submerged, and the newly submerged area soils mainly adsorbed $P$ from the water, unless the level of $P$ concentrations in water decreased.

\section{Conclusions}

The arable land was the highest TP content values in all land using types in the new submerged area of the Danjiangkou Reservoir, especially above the elevation of $160 \mathrm{~m}$. The mean content values of P-fractions ranked order was: $\mathrm{HCl}-\mathrm{P}>\mathrm{OP}>\mathrm{NaOH}-\mathrm{P}$. The $P$ sorption on soils was mainly occurred within $20 \mathrm{~h}$ and then reached to dynamic equilibrium. The $P$ sorption rates were obviously affected by the TP contents in soils. There was no significant correlation between soil compositions and the maximum phosphate sorption capacity. The $\mathrm{P}$ was not strongly enriched in the study area and the potential risk of $P$ in soils was minimal in the newly submerged area of Danjiangkou Reservoir at present; besides, the risk would be varying according to the P concentrations of the overlying water, and it's difficult to accurately determine which areas are source or sink when submerged. Thus more studies are urged in consideration that the reservoir will run for many years and has a far-reaching influence.

\section{Acknowledgments}

This research was supported by the One-Three-Five Program of the Research Center for Eco-Environmental Sciences (No. YSW2013B02), the Youth Innovation Promotion Association CAS (Wenzhong Tang), and the National Environmental Protection Public Welfare Science and Technology Research Program of China (No. 201509027).

\section{Appendix A. Supplementary data}

Supplementary data associated with this article can be found, in the online version, at http://dx.doi.org/10.1016/j.ecoleng.2016.11. 072 . 


\section{References}

Ahlgren, J., Tranvik, L., Gogoll, A., Waldeback, M., Markides, K., Rydin, E., 2005. Sediment depth attenuation of biogenic phosphorus compounds measured by P-31 NMR. Environ. Sci. Technol. 39, 867-872.

Ahlgren, J., Reitzel, K., De Brabandere, H., Gogoll, A., Rydin, E., 2011. Release of organic P forms from lake sediments. Water Res. 45, 565-572.

Aye, T.M., Nguyen, M.L., Bolan, N.S., Hedley, M.J., 2006. Phosphorus in soils of riparian and non-riparian wetland and buffer strips in the Waikato area, New Zealand. N. Z. J. Agric. Res. 49, 349-358.

Baliarsingh, N., Parida, K.M., Pradhan, G.C., 2013. Influence of the nature and concentration of precursor metal ions in the brucite layer of LDHs for phosphate adsorption - a review. RSC Adv. 3, 23865-23878.

Borggaard, O.K., Raben-Lange, B., Gimsing, A.L., Strobel, B.W., 2005. Influence of humic substances on phosphate adsorption by aluminium and iron oxides. Geoderma 127, 270-279.

Carpenter, S.R., 2005. Eutrophication of aquatic ecosystems: bistability and soil phosphorus. Proc. Natl. Acad. Sci. U. S. A. 102, 10002-10005.

Dong, L.M., Yang, Z.F., Liu, X.H., 2011. Phosphorus fractions, sorption characteristics, and its release in the sediments of Baiyangdian Lake, China. Environ. Monit. Assess. 179, 335-345.

Dunne, E.J., Coveney, M.F., Marzolf, E.R., Hoge, V.R., Conrow, R., 2013. Efficacy of a large-scale constructed wetland to remove phosphorus and suspended solids from Lake Apopka, Florida (vol 42, pg 90, 2012). Ecol. Eng. 52, 316-316.

Edwards, A.C., Withers, P.J.A., 2007. Linking phosphorus sources to impacts in different types of water body. Soil Use Manage. 23, 133-143.

Eveborn, D., Gustafsson, J.P., Elmefors, E., Yu, L., Eriksson, A.K., Ljung, E., Renman, G., 2014. Phosphorus in soil treatment systems: accumulation and mobility. Water Res. 64, 42-52.

Gee, G.W., Bauder, J.W., 1986. Particle-size analysis. In: Klute, A. (Ed.), Methods of Soil Analysis: Part1-Physical and Mineralogical Methods. SSSA Book Series, vol. 5, 2nd ed. Soil Science Society of America, Madison, WI.

Huo, S.L., Zan, F.Y., Xi, B.D., Li, Q.Q., Zhang, J.T., 2011. Phosphorus fractionation in different trophic sediments of lakes from different regions, China. J. Environ. Monit. 13, 1088-1095.

Jarvie, H.P., Jurgens, M.D., Williams, R.J., Neal, C., Davies, J.J.L., Barrett, C., White, J., 2005. Role of river bed sediments as sources and sinks of phosphorus across two major eutrophic UK river basins: the Hampshire Avon and Herefordshire Wye. J. Hydrol. 304, 51-74

Jarvie, H.P., Sharpley, A.N., Brahana, V., Simmons, T., Price, A., Neal, C., Lawlor, A.J., Sleep, D., Thacker, S., Haggard, B.E., 2014. Phosphorus retention and remobilization along hydrological pathways in karst terrain. Environ. Sci. Technol. 48, 4860-4868.

Jin, X.D., He, Y.L., Kirumba, G., Hassan, Y., Li, J.B., 2013. Phosphorus fractions and phosphate sorption-release characteristics of the sediment in the Yangtze River estuary reservoir. Ecol. Eng. 55, 62-66.

Kronvang, B., Bechmann, M., Lundekvam, H., Behrendt, H., Rubaek, G.H., Schoumans, O.F., Syversen, N., Andersen, H.E., Hoffmann, C.C., 2005. Phosphorus losses from agricultural areas in river basins: effects and uncertainties of targeted mitigation measures. J. Environ. Qual. 34, 2129-2144.

Lazzarotto, P., Prasuhn, V., Butscher, E., Crespi, C., Fluhler, H., Stamm, C., 2005. Phosphorus export dynamics from two Swiss grassland catchments. J. Hydrol. 304, 139-150.

Lin, C.Y., Wang, Z.G., He, M.C., Li, Y.X., Liu, R.M., Yang, Z.F., 2009. Phosphorus sorption and fraction characteristics in the upper, middle and low reach sediments of the Daliao river systems, China. J. Hazard. Mater. 170, 278-285.

Lopez, P., Lluch, X., Vidal, M., Morgui, J.A., 1996. Adsorption of phosphorus on sediments of the balearic islands (Spain) related to their composition. Estuarine Coastal Shelf Sci. 42, 185-196.

McDowell, R., Sharpley, A., Withers, P., 2002. Indicator to predict the movement of phosphorus from soil to subsurface flow. Environ. Sci. Technol. 36, 1505-1509.

Mellander, P.E., Jordan, P., Melland, A.R., Murphy, P.N.C., Wall, D.P., Mechan, S., Meehan, R., Kelly, C., Shine, O., Shortle, G., 2013. Quantification of phosphorus transport from a karstic agricultural watershed to emerging spring water. Environ. Sci. Technol. 47, 6111-6119.

Pan, G., Krom, M.D., Herut, B., 2002. Adsorption-desorption of phosphate on airborne dust and riverborne particulates in East Mediterranean seawater. Environ. Sci. Technol. 36, 3519-3524.
Pan, G., Krom, M.D., Zhang, M.Y., Zhang, X.W., Wang, L.J., Dai, L.C., Sheng, Y.Q., Mortimer, R.J.G., 2013. Impact of suspended inorganic particles on phosphorus cycling in the yellow river (China). Environ. Sci. Technol. 47, 9685-9692.

Pardo, P., Rauret, G., Lopez-Sanchez, J.F., 2004. Shortened screening method for phosphorus fractionation in sediments - a complementary approach to the standards, measurements and testing harmonised protocol. Anal. Chim. Acta 508, 201-206.

Peng, J.F., Wang, B.Z., Song, Y.H., Yuan, P., Liu, Z.H., 2007. Adsorption and release of phosphorus in the surface sediment of a wastewater stabilization pond. Ecol. Eng. 31, 92-97.

Pionke, H.B., Gburek, W.J., Sharpley, A.N., 2000. Critical source area controls on water quality in an agricultural watershed located in the Chesapeake Basin. Ecol. Eng. 14, 325-335.

Ribeiro, D.C., Martins, G., Nogueira, R., Cruz, J.V., Brito, A.G., 2008. Phosphorus fractionation in volcanic lake sediments (Azores, Portugal). Chemosphere 70, 1256-1263.

Ruban, V., Lopez-Sanchez, J.F., Pardo, P., Rauret, G., Muntau, H., Quevauviller, P., 1999. Selection and evaluation of sequential extraction procedures for the determination of phosphorus forms in lake sediment. J. Environ. Monit. 1, 51-56.

Sattari, S.Z., Bouwman, A.F., Giller, K.E., van Ittersum, M.K., 2012. Residual soil phosphorus as the missing piece in the global phosphorus crisis puzzle. Proc. Natl. Acad. Sci. U. S. A. 109, 6348-6353.

Schindler, D.W., Hecky, R.E., Findlay, D.L., Stainton, M.P., Parker, B.R., Paterson, M.J., Beaty, K.G., Lyng, M., Kasian, S.E.M., 2008. Eutrophication of lakes cannot be controlled by reducing nitrogen input: results of a 37-year whole-ecosystem experiment. Proc. Natl. Acad. Sci. U. S. A. 105, 11254-11258.

Siciliano, S.D., Chen, T.T., Phillips, C., Hamilton, J., Hilger, D., Chartrand, B., Grosskleg, J., Bradshaw, K., Carlson, T., Peak, D., 2016. Total phosphate influences the rate of hydrocarbon degradation but phosphate mineralogy shapes microbial community composition in cold-region calcareous soils. Environ. Sci. Technol. 50, 5197-5206.

Sondergaard, M., Bjerring, R., Jeppesen, E., 2013. Persistent internal phosphorus loading during summer in shallow eutrophic lakes. Hydrobiologia 710, 95-107.

Storkey, J., Macdonald, A.J., Poulton, P.R., Scott, T., Kohler, I.H., Schnyder, H., Goulding, K.W.T., Crawley, M.J., 2015. Grassland biodiversity bounces back from long-term nitrogen addition. Nature 528, 401-412.

Stutter, M.I., Langan, S.J., Lumsdon, D.G., 2009. Vegetated buffer strips can lead to increased release of phosphorus to waters: a biogeochemical assessment of the mechanisms. Environ. Sci. Technol. 43, 1858-1863.

Ulen, B., Bechmann, M., Folster, J., Jarvie, H.P., Tunney, H., 2007. Agriculture as a phosphorus source for eutrophication in the north-west European countries, Norway, Sweden, United Kingdom and Ireland: a review. Soil Use Manage. 23, $5-15$.

Wilfert, P., Kumar, P.S., Korving, L., Witkamp, G.J., van Loosdrecht, M.C.M., 2015. The relevance of phosphorus and iron chemistry to the recovery of phosphorus from wastewater: a review. Environ. Sci. Technol. 49, 9400-9414.

Williams, J.D., Syers, J.K., Harris, R.F., Armstron De, 1970. Adsorption and desorption phosphorus by lake sediments in a $0.1 \mathrm{M} \mathrm{NaCl}$ system. Environ. Sci. Technol. 4, 517-524.

Williams, J.D., Syers, J.K., Shukla, S.S., Harris, R.F., 1971. Levels of inorganic and total phosphorus in lake sediments as related to other sediment paramenters. Environ. Sci. Technol. 5, 1113-1129.

Zhang, J.Z., Huang, X.L., 2007. Relative importance of solid-phase phosphorus and iron on the sorption behavior of sediments. Environ. Sci. Technol. 41, 2789-2795.

Zhang, R., Wu, F.C., Liu, C.Q., Fu, P.Q., Li, W., Wang, L.Y., Liao, H.Q., Guo, J.Y., 2008. Characteristics of organic phosphorus fractions in different trophic sediments of lakes from the middle and lower reaches of Yangtze River region and Southwestern Plateau, China. Environ. Pollut. 152, 366-372.

Zhang, B., Fang, F., Guo, J.S., Chen, Y.P., Li, Z., Guo, S.S., 2012. Phosphorus fractions and phosphate sorption-release characteristics relevant to the soil composition of water-level-fluctuating zone of Three Gorges Reservoir. Ecol. Eng. 40, 153-159.

Zhu, Y.R., Wu, F.C., He, Z.Q., Guo, J.Y., Qu, X.X., Xie, F.Z., Giesy, J.P., Liao, H.Q., Guo, F., 2013. Characterization of organic phosphorus in lake sediments by sequential fractionation and enzymatic hydrolysis. Environ. Sci. Technol. 47, 7679-7687. 